\title{
Class and Politics in the Greek Debt Crisis
}

\author{
Vassilis K. Fouskas \& Constantine Dimoulas
}

The mainstream view on the causes of the Euro-zone crisis is that it is a fiscal crisis emanated partly from the incompetence of the peripheral EU states to collect taxes, partly from their own states' profligacy with a huge and uneconomic public sector, and partly from the "fact" that these societies are not working very hard as their northern neighbours. This view has been defeated by original work carried out in the past few years not only by Marxisant scholars and heterodox economists, but also by important financial commentators and journalists, such as Martin Wolf of the Financial Times. The Euro-zone crisis, this winning approach argued, is a balance of payments crisis that is bound up with Germany's anti-inflationary, low wage, export-led growth creating permanent surpluses for herself and permanent deficits for the periphery. This chapter aims at going a step further. By offering a historical reading of the Greek social and political economy, it brings into context political and agential aspects of the crisis, that is, a class analysis of the Greek situation. The thesis advanced is that Greece's dominant capitalist class has always been a comprador one, which from the early 1990s onwards it began diversifying its main activities following the global trend of financialization and the insertion of Greece into the Euro-zone. It is argued that this class and its politicoideological ramifications constitute the most parasitic and corrupt element of Greek society and politics that any left alternative has to confront head on.

\section{Introduction}

From at least 2009 onwards, successive Greek governments, including the left radical government of Syriza (Coalition of the Radical Left) accepted a humiliating process of negotiation with, and subordination to, their foreign creditors in order to maintain the country in the EMU at all costs. The terms of the bailout agreements, three in total, were even more humiliating. Although it falls outside the scope of this chapter to examine them in detail, it is worth reminding their key pillars. First, they passed onto the public institutions most part of the debt so that the Greek taxpayer will have to foot the bill via an unprecedented set of austerity measures which, over the last five years, caused social havoc: $26 \%$ loss of GDP, massive unemployment and a further increase in the debt to GDP ratio (from 118\% in 2010 to $178 \%$ today). Second, they subjugated key departments of the Greek state to a number of European committees and assessors, which control directly the policy management structures of key Ministries. In a way, this can be justified via the official process of the "European Semester" mechanism led by the Commission, which oversees the budgets of all current and future EU member-states. But there are also important details we do not know. One such detail was revealed by the former Greek Minister of Finance, Yanis Varoufakis. While trying to test his "Plan B" back in May-June 2015 in case negotiations with the creditors failed, he was surprised to find out that even the General Secretariat for the Public Revenue based in his Ministry was controlled by the creditors (Varoufakis 2015). Thus, his contingency plans could not come to fruition. 
All Greek governments had to turn the bailout agreements into State Law via an authoritarian parliamentary process of decree issuing and scaremongering, let alone that the agreements themselves are against the letter and spirit of the Greek Constitution (Pavlopoulos 2011). To all intents and purposes, the EU, under the hegemony of its key creditor and industrial power, Germany, and the tutelage of global banking and financial institutions, is evolving into a neo-colonial regime of formal control and expansion promoting authoritarianism instead of democracy and solidarity in order to satisfy the monetarist and neomercantilist requirements that are at the core of the EMU discipline as a monetary regime.

As the bailout agreements transferred onto the taxpayer the burden of Greece's debt obligations, an ideology should be put in place to justify austerity. It has thus been argued that the causes of the Greek (and Euro-zone) crisis is that it is a fiscal crisis emanated partly from the incompetence of the Greek (and other peripheral EU) state(s) to collect taxes, partly from their own states' profligacy with a huge and uneconomic public sector, and partly from the "fact" that these societies are not working very hard as their protestant northern neighbours. This ideology has been defeated by original work carried out in the past few years not only by Marxisant scholars and heterodox economists, but also by important financial commentators and journalists, such as Martin Wolf of the Financial Times (Wolf 2012 and 2013). The Eurozone crisis, this winning approach argued, is a balance of payments crisis that is bound up with Germany's anti-inflationary, low wage, export-led growth creating permanent surpluses for herself and permanent deficits for the periphery. At a more theoretical, yet substantive, level, the Euro-zone crisis pertains to the uneven historical developmental structures of European economies, which are creating and reproducing a number of economic and political disequilibria across the EU and EMU, undermining convergence and promoting disintegration.

This chapter aims at advancing these debates further. By offering a historical reading of Greece's social and political economy from the 1990s onwards, it brings into context agential aspects of the story hitherto unexamined, that is, it advances a class analysis of the Greek crisis. The thesis put forward is that Greece's dominant capitalist class has always been a comprador one, which from the early 1990s onwards it began diversifying its main activities following the global trends of financialization, European monetary integration and, eventually, the insertion of Greece into the EMU in 2001. It is argued that this class constitutes the most parasitic and corrupt element of Greek society and politics and that it is the transnational and subordinate connections of this class, together with its political representatives, that is chiefly responsible for the creation of the debt and how it was managed politically.

We will first deal with the global context of the problem and the issue of "power-shift" to Asia. Then we will concentrate on the class origins of the Greek debt crisis by way of combining historical and contemporary perspectives, thus viewing it as a symptom of global structural forces and shifts. It will transpire that Greece was used by the West as a platform to advance neo-liberal financialization in the Balkans and the Near East and that the so-called "growth years" of 2000-2006 were, like everywhere else in the West, comprehensively debtdriven.

\section{The global context and the issue of neo-liberal financialization}


Arguably, the provenance of the financial crisis which hit the Anglo-Saxon economies in summer 2007 can be traced back to the 1970s. This was the decade of two oil-shocks, stagflation and collapse of profitability in the real economic sector and, fundamentally, President Nixon's decision to get rid of the Gold fetter (Gowan 1999, Brenner 2003). The end of the Gold-Dollar parity and of fixed exchange rates unleashed financialisation in historically unprecedented ways (Glyn 2007, Aglietta 2008, Fine 2010, Duncan 2012): credit and financial flows expanded exponentially, a process that was accompanied by massive growth in the volume of global trade and FDI, including portfolio investment, asset management activity, mergers and acquisitions and extreme speculation in currency and derivatives markets. Oil trade has been peculiarly dollarised (Fouskas \& Gökay 2005). What is hiding behind the term "globalisation" is in fact a process of extreme financialisation, that is, activity of unfettered and uncommitted capital, capital which is not conducive to real commodity production (Fouskas \& Dimoulas 2013, Wolfson and Epstein 2013) and sustainable economic development. In the indebted West today, the real economic sector has receded, giving way to fictitious capital activity, speculative arbitrage, services and consumption, all of which are prone to boom and bust cycles, vast consumer indebtedness and extreme volatility and risk. Financial capital and generalised indebtedness have permeated the daily life of Western citizenship. Financialisation is the first monumental transformation that occurred in the OECD economies in the wake of the collapse of the Bretton Woods system in the late 1960s. This transformation was led by the USA.

The second massive transformation of social and political relations, the sister-tendency of US-led financialisation, goes under the name of neo-liberalism. This term, primarily, applies to the domestic environment of the state. For some, overcoming stagflation and the fiscal crisis of the state in the 1970s entailed the following: the welfare state must be retrenched; labour markets, banks and finance should be deregulated and state enterprises should be privatised. By "deregulation" is meant moving those agencies from state to private ownership and, in the case of labour unions, freeing them from state protection. This did not mean an end of state interference, inasmuch as the neo-liberal capitalist state has moved to "regulation via legislation" and coercion (Sassoon 1996; Panitch 2012). Neo-liberal regimes of financial accumulation are almost entirely based on a set of complex regulations advanced by the legislative branch of the bourgeois state (Lapavitsas 2013), whereas class resistance to them is met with state coercion and policing. In this context, by the early $1980 \mathrm{~s}$, governing elites, whether on the Left or the Right, abandoned Keynesianism, giving way to supply-side economics.

Essentially, neo-liberalism and financialisation were the responses of the West to the profitability crisis in the 1970s. Yet the failure of this strategy to restore profitability and growth rates has been spectacular; in addition, it has failed to arrest the slow and protracted decline of the Western core as a whole. This slow decline of the core goes hand in glove with the complex -- and debatable for some scholars -- ascendance of China and other emerging economies, especially after the end of the Cold War. China dominates the world market in rare earth elements (a class of minerals that are essential for electronics and computers) and has become the second largest economy in the world -- it overtook Japan in February 2011. China has become the engine driving the recovery of other Asian economies from the recessions of the 1990s. In September 2013, the British Chancellor of the Exchequer, George Osborne, rolled out the red carpet for Chinese banks looking to expand in London, making the City a significant Chinese offshore banking centre. China has already captured a large share of Africa's oil and minerals market and dominates the textiles industry in Latin America. China and India produce a combined total of more than half a million engineering and science graduates per year. The 
respective numbers for the USA is 60,000 . Although financialised and integrated into a global economy in which the dollar remains the key reserve currency, the real economic output of the so-called BRICS is healthy and their debt levels very low (Fouskas and Dimoulas 2013, 136).

Financialisation increased the global debt in the time span of a decade (2002-2012) in every country except China, India, Brazil, Russia and South Africa. But where does Europe figure in all this?

During the "Golden Age of Capitalism" of the 1950s and 1960s (Hobsbawm 1995), Germany re-asserted itself as Europe's economic powerhouse. As Robert Brenner and others have argued, it was mainly competition from German and Japanese capitals that drove the downward spiral of the rate of profit in the Anglo-Saxon world (Brenner 2006, Busch 1976). Germany drove the process of European integration outflanking France, something which was pointed out already in the late 1960s by such scholars as Nicos Poulantzas and Christian Palloix in France, and Elmar Altvater in West Germany (Poulantzas 1974; Palloix 1975). Soon, however, problems appeared. How to reconcile the tension between "deepening" and "widening", ie, pushing for more capitalist integration in the direction of a (federal) United States of Europe, and enlarging in consecutive steps (from 6 countries in 1957 to 27 countries in 2010)? How could the pronounced developmental gap between the core and the periphery be bridged? With a customs union at hand since the Treaty of Rome, and prompted by the monetary instability of the late 1960s, the Europeans pushed for monetary integration with the Werner Report of 1970. It came to naught due to American pressure, yet many in Europe at the time believed that Europe's economic space represented an "optimal currency area" -- as Robert Mundell put it in a celebrated article in 1961 -- an ideal regional economy almost perfect for monetary integration (Mundell 1961). This indeed was the view that more or less dominated Europe's policy-making establishment until the breakout of the current crisis. Their concern was to eliminate currency crises, exchange rate instability and risk.

This is the first fallacy, namely that uneven and deeply asymmetrical levels of economic development across Europe could be bridged by putting all currencies into the same hat and then, miraculously, levelling out uneven development and structural fault-lines by pulling the rabbit out of the hat -- the Euro, a currency lacking the political and fiscal support of a state. The second fallacy is called financialisation. From the 1980s onwards the dominant forces behind the processes of "deepening" and "widening" were other than Keynesian; they were deeply pro-monetarist, mercantilist forces, as if Europe had been "Hayek-jacked". The emphasis, also because of pressure from Britain and the USA, was on "widening" rather than "deepening". Neo-liberalism and financialisation suited Germany very well, but one should not confuse the German model with the Anglo-Saxon one. German banks do not operate in the same way as British or American banks (Lapavitsas 2013). The Anglo-American model is driven by consumption and debt; the German by an anti-inflationary, export-led growth regime. These differences are very significant. From the Single European Act of 1986 to the Maastricht Treaty of 1991, and from the Growth and Stability Pact of 1997 to the launch of the Euro in 1999 and after, the process of European integration has been subjected to a neo-mercantilist bias emanating from a relentless German strategy of export-led growth and wage suppression. The monetarist character of the Maastricht criteria was the result of this type of German discipline. From the mid-1990s onwards, and in order to increase profitability and price competitiveness, Germany put enormous downward pressure on wages (Stockhammer 2013)

Low wages, coupled with the institutional capacity of the German state and the dynamism of its real economic sector, magnified the existing gap between core and periphery. As we shall see, the introduction of EMU in 1999 exacerbated the asymmetries and monetary 
imbalances across Europe. Thus, when the global financial crisis trickled down to the Eurozone via the banking sector -- German and European banks had bought 40 per cent of American CDOs (Collateralised Debt Obligations) and other toxic assets -- the disintegrative tendencies of the EU multiplied over-night. Greece has been and remains the weak link in Europe's and the globe's financialisation chain.

\title{
Three views on the Greek crisis
}

The most authoritative view that considers the external environment of the peripheral/debtor state as the main cause of the debt crisis in Europe comes from Martin Wolf. In a lecture he gave in London on 3 October 2012, the chief economics commentator of the Financial Times argued:

\author{
This is not, in its origin, a fiscal crisis, but a balance of \\ payments cum financial crisis. In the run up to the crisis, there \\ were huge internal capital flows. These opened up current \\ account imbalances and generated huge divergences in \\ competitiveness. After 2008, cross-border private financial \\ flows suffered a series of 'sudden stops'. These caused, or \\ aggravated, a fiscal crisis (Wolf 2012)
}

An almost identical thesis was advanced by Costas Lapavitsas et al., at least as far as the origins of the crisis was concerned: 'The crisis', it is argued in a Report produced by the group 'Research on Money and Finance' based at SOAS, University of London, 'is not due to fiscal profligacy (...). Its roots lie in the loss of competitiveness by the periphery coupled with an enormous financial expansion in the 2000s' (Lapavitsas et al. 2011; Lapavitsas et al. 2010) Germany, due to its suppression of wages, became far more competitive than any other European country, a fact that enabled it to recycle its financial surpluses across Europe rendering especially the periphery and Greece with huge financial account surpluses. In short, this tendency sees the crisis emanating from the financial sector, which facilitated borrowing for the periphery via low interests rates, especially in the 1990s and early 2000s. But when this came to an end from the mid-2000s onwards, and especially with the onset of the financial crisis in summer 2007, the equilibrium was destroyed. With the global financial crisis setting in, rising interest rates exposed the public and private sectors, which were now in possession of large amounts of bad securitised paper/debt that belonged to the periphery. Lapavitsas, in addition, goes as far as to argue that the EMU has created a split between core and periphery, creating discriminatory and hierarchical relations between the two. The cure, in this respect, is a debtor-led default and exit from the Euro-zone, imposition of exchange controls followed by a new industrial policy and the introduction of a new national currency. As far as the banking sector is concerned, it should be nationalised. This Left strategy would have the additional benefit of breaking the yoke of austerity in the rest of Europe, especially Germany, which would be forced to boost aggregate demand and rise wages in order to boost domestic consumption. 
These analyses make a lot of sense especially from a 'structuralist' point of view. Technically, there is no doubt that the debt crisis in the periphery was triggered from outside the periphery state. But this was the trigger, for the underlying causes are much more diverse and complex. The thesis is vulnerable especially when we bring into the picture agency and history. As we have seen, the split between core and periphery in Europe has not been caused by the introduction of the EMU. Core-periphery relations are enshrined in the structural and historical reproduction of capitalism as a global social system and pertain to Greece's peculiar form of dependency and subordination upon the core. Greece and other periphery countries in Europe and the world do not need to participate in any monetary union whose usurious and imperial effects would be to lead them to bankruptcy and default. Greece has defaulted several times in its history and has constantly been in a debt spiral without participating in any currency union - indeed having its currency pegged to an imperial currency was good enough to trigger bankruptcy given the vulnerability and weaknesses of the country's productive and technological sectors (Fouskas \& Dimoulas 2013). Most likely, it would have defaulted on its debt obligations even without participating in the EMU since 2001, and it could have defaulted earlier, in the late 1980s or early 1990s, had it not been for the challenges created in its northern borders by the collapse of the Soviet Union (NATO's and EU's eastward expansion, oil and gas pipeline projects, projection of financialisation into the Balkans and so on). Both financialisation and the collapse of 'really existing socialism' in its northern borders had simply given Greece another fifteen years lease of life. Bankruptcy would have happened anyway, with or without participation in the EMU. In the end, the forms of dependency and subordination of Greece are not just economic. They are also political.

The second tendency in the recent literature on Greece sees the fiscal component of the state as the main culprit for generating the unprecedented debt crisis of 2010-2013. The focus here is on the institutional weakness of the Greek state, its fiscal malaise and inability to enforce tax collecting mechanisms, the issue of political clientelism and so on. As two representatives of this tendency put it:

The capacity of the Greek economy to exercise effective counter-cyclical expansion has been fatally undermined by its chronic inability to exercise fiscal discipline when the economy was still expanding (...) The inadequate progress in improving long-term fiscal sustainability is demonstrated in a public debt to GDP ratio (...) Excessive public indebtedness reflects diachronic weaknesses including inefficient public administrative and budgetary structures, inadequate collection of revenues and tax evasion, high defence spending, and a tradition of clientelistic appointments in the public sector (Pagoulatos \& Triantopoulos, 2009).

Other similar views come from assessors and researchers from the Economic Research Department (ERD) of the Bank of Greece, experts and assessors of the ECB, and think-tanks around the Directorate-General for Economic and Financial Affairs of the European Commission: 
(...) Deep-seated problems in the Greek economy remained unaddressed, reflecting a pro-cyclical fiscal policy; as a result, the country continued to run large fiscal and external deficits (...) The widening of the deficits was mainly expenditure-driven (...) The large and widening fiscal deficits contributed to growing current-account deficits (..) In the case of Greece, the widening of the current account deficit was caused entirely by the behaviour of the public sector (Dellas \& Tavlas, 2012)

It is interesting here to note how this tendency minimises the external dimension of the crisis (low interest rates and high borrowing, current account imbalances, financial flows etc.) in order to attribute to the state primary responsibility for causing the Greek debt problem. The second extract, in particular, considers the current account deficit as driven entirely by the state, a thesis which is rather flippant. As one of the two main expressions of the balance of payments - the other being 'capital/financial account' - current account does straddle the domestic and external environments of the state, the determining factor being the social productive basis of the state. Germany was in a position to recycle its financial surpluses which were constantly entering and exiting the periphery states' accounts proliferating their debt ratio, precisely because it had the strongest industrial/institutional structure in the Euro-zone. The aspect of social relations of production is wholly ignored by this tendency and together the real interaction between the domestic and external sources of debt creation. The solution proposed by this tendency is close to that of the troika: strict anti-inflationary policies, harsh austerity measures, cutting down the size of the public sector, complete welfare state retrenchment the aim being the creation of primary surpluses in order to serve debt repayments.

The third tendency, around which a number of European economists, neo-Marxists and various left Europeanists converge, is that the European project has been deficient from its birth and the real problem is 'neither Greece nor Germany but the system of the Euro' (Milios \& Sotiropoulos, 2010). Despite the variations and tensions within this current, they all seem to accept that the real cause of the crisis lies at the heart of the European project, which also becomes the privileged terrain of political struggle for overcoming the crisis. In this respect, one of the most interesting and progressive approaches comes from John Milios and the group around the journal Thesseis ('Positions') based in Greece.

Following Leo Panitch's analyses, Milios et al. argue that neo-liberal globalisation has not only solved the problem of capitalist profitability which dominated the stagflation period, but also facilitated real economic convergence between centre and 'periphery', especially within the Euro-zone (Lapatsioras et al., 2009). This can be seen from the high rates of growth and profitability in the 'periphery' - Milios et al. do not accept 'world systems and dependency' theories, hence their usage of inverted commas for the term 'periphery' - ten years before the crisis and the large financial surpluses circulating in Greece and other 'periphery' states. In fact, it was the high rates of development in the 'periphery' which 'attracted 'savings' from the 'centre', financing increased demand.' This view was first formulated in 1990 and argues that Greece's current account deficit is sustainable to the extent that the conditions of profitability for capital are good and Greece attracts foreign investments and invisible earnings (e.g. 
emigrants' remittances) (Milios \& Ioakimoglou 1990). The authors assumed that the conditions that prevailed in the 1960s will continue to be the same, now under the aegis of German capital:

The perspective of Common European Market (...) is expected to boost the inflow of foreign (investment) capital in Greece to such a degree that: (a) it will boost the penetration of foreign commodities in the Greek market and (b) it will be accompanied by a corresponding augmentation of the marginal efficiency of concrete domestic business units and branches (Milios \& Ioakimoglou 1990, 172).

On the basis of this assessment, this tendency argues that Germany's 'economic locomotive' in Europe would bring about positive results for the Greek economy in the 1990s, whereas European capitalism as a whole does not generate internal tendencies of disintegration of its exchange rate system. This view proved to be short-sighted, for the authors disregarded completely uneven development and the fact that the growth registered was unsustainable and artificial because it was debt-driven. As we shall show below, the 'German economic locomotive' and the EMU contributed to the further disintegration of Greece's and the European periphery's productive base. In the end, this tendency illustrates that 'financial account surpluses in the periphery are responsible for the ballooning of current account deficits' (Milios \& Sotiropoulos 2010, 230). It is herein, moreover, that lies the innate deficiency and contradiction of the Euro-project:

On the one hand, the symbiosis within the Euro-zone has until now been built upon persistent financial account imbalances mostly due to different rates of growth and profitability. On the other hand, without the latter it would be difficult for the Euro-zone to exist, because it is at the same time a way of offsetting the pressures imposed upon labour (Milios \& Sotiropoulos, 236).

But this argument is circular because the 'surplus' which is enshrined in the structure of financial (capital) account is in fact a form of debt with claims on the assets and individuals of peripheral countries. As we shall try to show below, financial surpluses circulating in Greece and the periphery were not going into investment projects and the real economy, but into consumption and easy profiteering via the banking system. Interestingly, this is the view adopted by the ruling group of Syriza, which elaborated a strategy of negotiating the debt problem of the country within the EMU, a strategy that failed miserably in February-July 2015, the result being the breaking-up of the party and the call for a new election on 20 September 2015 .

Obviously, the approaches we have just reviewed are but a fraction of the growing scholarly literature on the subject of Greece/Euro-zone debt crisis. However, they are indicative of what dominates the current scholarly debates, thus offering readers with the necessary yardstick to assess our own analyses. Our main concern is to identify the causes of the current crisis and the agencies driving it. Looking at the structural/technical parameters of the crisis as economists usually do is not good enough: (class) agency, history and comparison hold the keys to a holistic understanding of our subject-matter, and indeed every subject matter at least in the field of social sciences. 


\section{Stock exchange bonanza and banks}

Greece did not simply have a problematic structure of public debt that appeared in the 1980s, something which was also true in the case of Italy, Belgium and other countries at the time. Greece had also tried to resist neo-liberalism and financialisation, but all the while lacking robust export-orientated sectors to buttress sustainable levels of development, thus matching the rising trend of its debt structure and the borrowing requirement (Fouskas 1997; Fouskas \& Dimoulas 2013). As Greece was moving out of the domain of Keynesian policy, and entering the structures of neo-liberalism in the 1990s, a new policy framework of speculative and rentier activities became entrenched, contributing to making even more problematic, unsustainable and unmanageable the domestic structures of debt by the ruling parties of PASOK and ND. The comprador element in the Greek social formation is the key in grasping the origins of the crisis as an articulation of domestic and external factors in the generation and mismanagement of the debt problem.

In the beginning it was asset capitalisation, equity and profits through the share price index in the Athens Stock Exchange (ASE). The bubble of the ASE was largely buttressed by privatisations and the underground economy, as those positioning themselves in the ASE and buying and selling shares were not required to prove their income status, or where their income came from. The bubble burst in September 1999, never to reach that level again (Table 1). As elsewhere in the West, the result of this speculative boom and bust cycle was to circulate paper assets and liquidity away from production, while concentrating wealth in the hands of very few speculators who 'cashed out and got out', switching the focus of their speculative activities elsewhere, mainly abroad. The loser, as usual, was the small investor - some 10 per cent of Greeks had bought shares on the stock market, an apotheosis of Greek 'popular capitalism', what Tony Blair in the late 1990s used to call the 'stakeholder society', the pillar of his 'Third Way'. European funds continued strengthening this fictitious liquidity by boosting the stock market with more than 3,500 million Euros every year since 1988. This chorus of shares and paper assets increased in the 2000s as more businesses entered the market and ramified their activities in the banking, financial and other services. Large amounts of accumulated income on the part of middle and lower middle classes were taken away, free of tax, from the financial capital through the ASE and without adding one iota to the competitiveness of the Greek economy. It is no accident that from the mid-1990s onwards hitherto unknown businessmen and companies appeared amassing a number of activities in Greece, the Balkans and the Near East, in the field of banking, construction, defence equipment and procurement (including offset agreements), large scale import-export, mass media, informatics and energy, all phenomena that should be seen in conjunction with the policies of privatisation and deregulation - the essence of Costas Simitis' 'modernisation' agenda after he assumed power in 1996 just before the death of Andreas Papandreou. 
Table 1: Athens Stock Exchange -Share price indices 1980-2010

Year Share Price Indices

$1980 \quad 74.9$

$1985 \quad 50.4$

$1990 \quad 488.3$

1995914.15

1996933.48

$1997 \quad 1,479.63$

$1998 \quad 2,737.6$

5,535.1 (on 17-9-1999

1999 it peaked at 6,335 )

$2000 \quad 3,388.9$

$2001 \quad 1748.4$

$2002 \quad 2,263.6$
Annual change in price indices

-24.5 (' $80-' 85)^{\prime}$

437.9('90-85)

425.85('90-95)

19.33

546.15

$1,257.97$

$2,797.5$

$-2,146.2$

$-1,640.5$

515.2

Source: Our compilation of data from Concise Statistical Yearbooks for the Respective Years, Hellenic Statistical Agency (ELSTAT)

From 1994 to 1999 more than 100 companies had been privatised, the most important being AGET-Hercules, the cement company; Hellenic Shipyards; Peiraiki Patraiki (textiles) and a number of banks, including ETVA (Hellenic Industrial Development Bank). The privatisation of Olympic Airways, the country's loss-making airline carrier, was blocked by its workers, but was eventually carried out in the late 2000s. ${ }^{1}$ Given the small size of the country, an unusual number of new commercial banks sprang up, including European and international banks and their subsidiaries. In the end, however, following privatisation, the Greek banking sector pursued a triple strategy.

First, instead of adopting an expansionary investment strategy to deal with increasing international competition vis-á-vis the country's entry into the Euro-zone, the Greek banks pursued an aggressive policy of mergers and acquisitions bringing about an oligopolistic

\footnotetext{
${ }^{1}$ It should be noted that all the privatisations that occurred from 1991 to 2010 brought only 20 billion Euros to the state, mainly used to sustain borrowing and the remaining lame-ducks.
} 
condition to the Greek financial sector and high profits. Greece has some 61 banks of which 34 are Greek, 33 branches which belong to banks from EU countries and five banks from outside the EU. But only five commercial banks control nearly 70 per cent of the liquidity market in Greece of which 80 per cent is owned by Greek banks.

It is worth noting that, according to the Governor of the Bank of Greece in 1998, the profitability of the Greek banks was much higher than in other European countries. But this happened due chiefly to the second type of strategy adopted by the banks, which was massive lending to the Greek government (Bank of Greece 2011, 273-77). For more than ten years (1999-2009), the Greek banks, through lending to the Greek governments, presented massive profits on their balance sheets, and at the expense of the Greek taxpayer (Fouskas \& Dimoulas 2013).

According to a research paper published by Constantine Manolopoulos (Manolopoulos 2011), in 2010 the National Bank of Greece had an accumulated holding of Greek debt of 17,9 million Euros, or 88,6 per cent of its investment portfolio; Piraeus Bank (of Sallas family) 7,3 million Euros or 83 per cent of its investment portfolio; EFG-Eurobank (of Latsis family) 7,3 million Euros or 97,1 per cent of its investment portfolio; Greek Postal Services (state-owned) 5,6 million Euros or 98,5 per cent of its investment portfolio; Alpha Bank (of Kostopoulos family) 4 million Euros or 87 per cent of its investment portfolio; AteBank (state-owned) 3,4 million Euros or 75,6 per cent of its investment portfolio; and the Commercial Bank, which is owned by the French Credit Agricole, 1,7 million Euro or 83,2 per cent of its investment portfolio.

Table 2. Mergers and acquisitions in the Greek Banking Sector 1997-2010

\begin{tabular}{|l|l|l|}
\hline Piraeus Bank & 1997 acquisitions of & $\begin{array}{l}\text { Chase } \\
\text { activities in Greece }\end{array}$ \\
\cline { 3 - 3 } & 1998 acquisitions of & Bank of Macedonia-Thrace \\
\cline { 3 - 3 } & Credit Lyonnais Greece \\
\cline { 2 - 3 } & 1999 acquisitions of & $\begin{array}{l}\text { Chios Bank } \\
\text { Westminster's Branches in } \\
\text { Greece }\end{array}$ \\
\hline & 2001 acquisitions of & $\begin{array}{l}\text { ETVA(Greek Bank for } \\
\text { Industrial Development) }\end{array}$ \\
\hline EFG-Eurobank & 1996 acquisitions of & Interbank \\
\hline
\end{tabular}




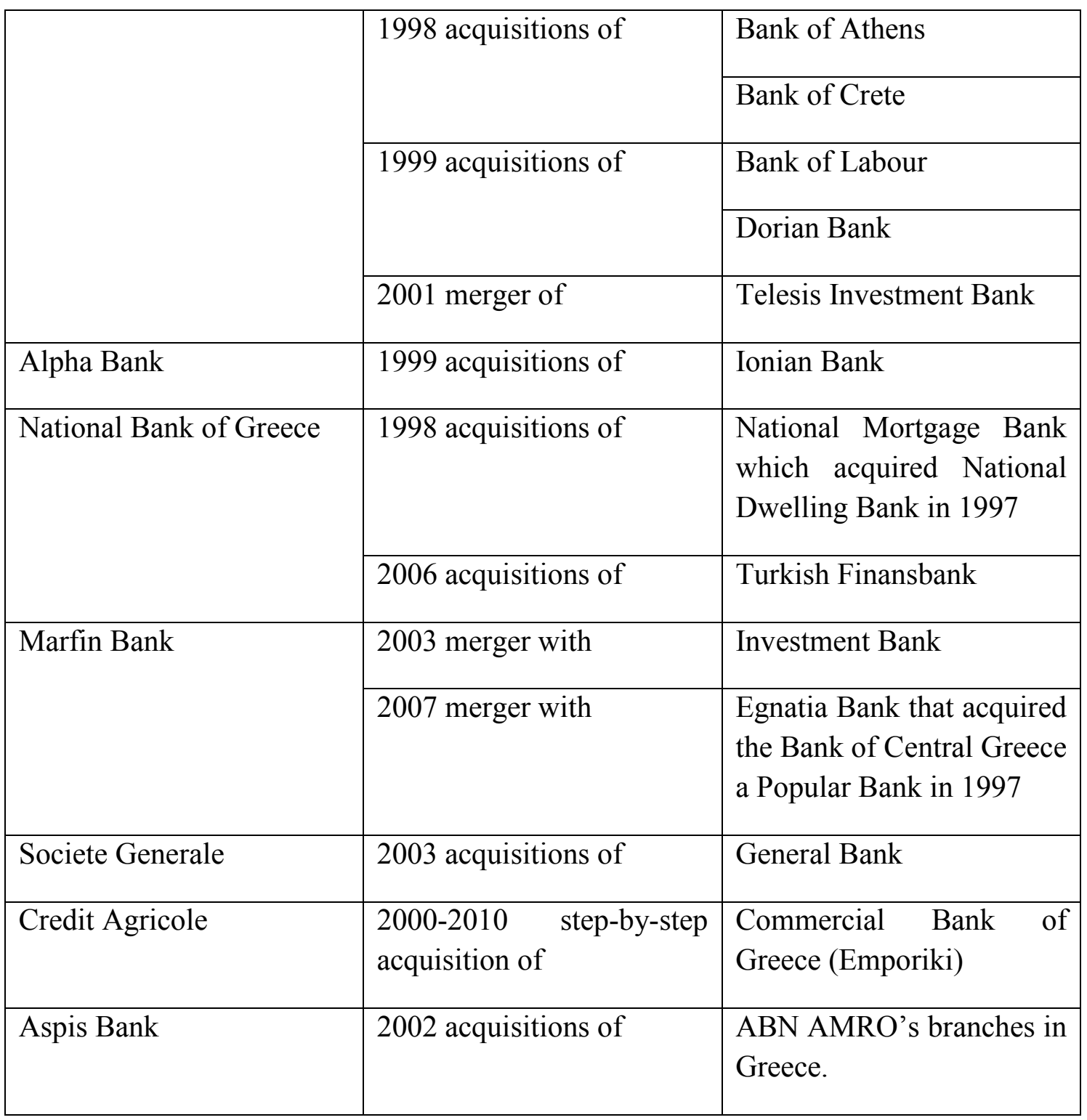

The third strategy pursued by the banks under this new regime of neo-liberal financialisation in order to increase their speculative profits and assets was the aggressive promotion of 'new products', such as mutual funds. These funds absorbed a significant amount of savings of ordinary people. The asset value of mutual funds in Greece was 1.1 per cent of GDP in 1990, 5 per cent in Portugal, 3.1 per cent in Spain, 5.5 per cent in Ireland and 3.7 per cent in Italy. But seven years later in 1997, the asset value of mutual funds soared to 22.4 per cent of GDP for Greece, 26 per cent for Portugal, 34,9 per cent in Spain, 69,9 per cent in Ireland, 18,9 per cent in Italy and 24.7 per cent in prudent Germany (Bank of Greece 1998, 279). We can see here the bubble of financialisation in the 1990s getting almost out of hand across Europe and not only in Greece, as well as Ireland standing out as a peculiar case with a high vulnerable banking sector. It is those paper assets (debt) which had been inserted in the statistics appearing as 'real' GDP growth, what in fact had been debt, portfolio and bond activity, as well as other services and products circulating in Greek, European and global markets. This all went hand 
in glove with the destruction of the productive (primary and secondary) sectors of the economy, which were now completely unable to compete internationally. Thus, when the crisis kicked in and blew up the chain of debts and paper assets across the European banking sector, the IMF and the ECB were among the first to step in to recapitalise them defending their Balkan kin, by which time it had amassed an amazingly brave operation in the financial and security markets of the Balkans and the Near East (table 3). By the end of 2011, the Greek banks had received 86.8 billion Euros from the ECB and nearly 30 billion Euros from the Greek government. But this is now taxpayer money that the Greek citizens have to pay. The creditors supports this solution because the assets of the Greek banks do not belong to any public utility whose main shareholders are the Greek people, but to investment funds and foreign interests holding nearly 82 per cent of their shares, whereas their official owners own less than 10 per cent and the Greek insurance fund less than 5 per cent.

Back in December 1996 cotton growers protested violently against the government, for refusing to reschedule about $\$ 1,3 \mathrm{bn}$ in debt owed to the state-controlled Agricultural Bank and to obtain reinstatement of a tax break on fuel. Strong protests also took place in Athens in 1998, when PASOK Finance Minister, Yannos Papantoniou, in coordination with the managing directors of the Commercial Bank, announced the tendering of a majority stake in its Ionian subsidiary. ${ }^{2}$ In 1998, the drachma was devalued by 12.1 per cent against the Ecu, as the price of entry to the ERM. By the end of the millennium, Greek state authorities were presenting highly positive statistical data vis-à-vis the country's entry into the Euro-zone, which was scheduled for 1 January 2001, two years after the launch of the Euro for the core of Europe: GDP was around 3.5 per cent, one of the highest in Europe; inflation was down to 4 per cent and the budget deficit had shrunk to 1.9 per cent of GDP, well below the Maastricht convergence ceiling of 3 per cent; the interest rate of 12-month Treasury bill in 1997-8 ran at 9.5\%, with the EMU fluctuating criterion being 7.8\%. Meanwhile, international lenders began bidding for contracts with the Greek government in the run up to the Athens Olympics of summer 2004, just as Greek rentier/financial capital penetration into the new Balkans/Near East assumed enormous proportions.

Table 3: International activities of Greek Banks in 2010

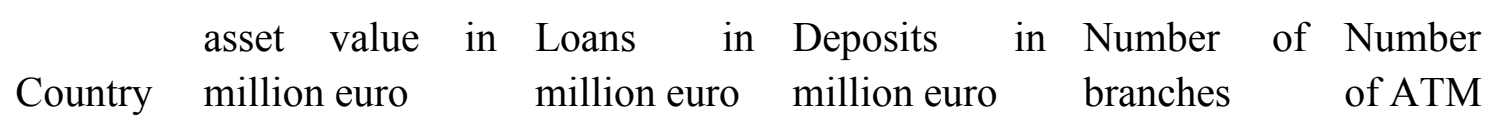

$\begin{array}{llllll}\text { Egypt } & 2018 & 979 & 1477 & 65 & 120 \\ \text { Albania } & 1750 & 1352 & 1223 & 157 & 212\end{array}$

\footnotetext{
${ }^{2}$ Interestingly, and when the Commercial Bank was in full neo-liberal swing, its managing director from 2000 to 2004 was Yiannis Stournaras, Minister of National Economy from June 2012 until January 2015.
} 


$\begin{array}{llllll}\text { Bulgaria } & 11461 & 9460 & 5530 & 706 & 1443 \\ \text { UK } & 6799 & 1447 & 1680 & 6 & 0 \\ \text { USA } & 628 & 394 & 544 & 13 & 16 \\ \text { Cyprus } & 13730 & 7688 & 8068 & 87 & 88 \\ \text { South } & & & & & \\ \text { Africa } & 141 & 121 & 107 & 11 & 7 \\ \text { Ukraine } & 1291 & 926 & 463 & 153 & 158 \\ \text { FYROM } & 1254 & 855 & 935 & 91 & 136 \\ \text { Poland } & 5693 & 5184 & 3262 & 335 & 0 \\ \text { Romania } & 17347 & 12506 & 5661 & 845 & 1387 \\ \text { Serbia } & 4931 & 3609 & 2160 & 471 & 514 \\ \text { Turkey } & 23348 & 16762 & 12444 & 556 & 1629 \\ & & & & & \\ \text { Total } & 90391 & 61283 & 43554 & 3496 & 5710\end{array}$

Source: Our own estimates based on data from the Union of Greek Banks (2011)

The new comprador element and the collusion between 'modernisation' and corruption

Companies such as the Alpha Group, Mytilineos S.A., Bobolas S.A., Intracom Holding S.A., Marfin Bank, MIG and the Sfakianakis Group, began dominating the new business environment. The Sfakianakis Group, for instance, which started in the early 1960s manufacturing buses, saw its profits declining in the 1980s and quickly diversified into comprador activities, becoming Greece's prime car importer from Germany, France Italy and the USA. Greece's telecommunications operator, OTE, while under a programme of partial privatisation, bought Romania's Rom Telecom defeating Telecom Italia, the only other bidder. US companies provided technology and other capital for further modernisation. The Mytilineos business group bought Romanian SC Somerta Copsa Mica, a lead and zinc smelter company, with a view to expanding it into metal processing boosting its supplies to Kosovo and Macedonia/FYROM. Cement manufacturing Titan, in a joint venture with Holderbank of Switzerland, acquired Macedonia's plant Cementamica USJE. Latsis, a London-based shipping 
company, participated in investment ventures in Bulgaria and Romania through the Euromerchant Balkan Fund, operated by Global Finance, a Greek venture capital fund manager. Around the same time, Spiro Latsis set up Eurobank EFG in Greece, the third largest private bank in Greece, recycling paper and values stemming from oil trade and equity investment in Poland, the Ukraine, Turkey, Serbia, Romania and Bulgaria. In this delirium, divided Cyprus, an EU member state since 2004, was an offshore paradise and tax haven accommodating rentier and financial activities, whether of Greek, British, Russian, Serbian or Persian Gulf origin. ${ }^{3}$ At the same time, Cypriot banks, which have a significant presence in the Greek market, kept buying Greek debt in increasing quantities. Thus, straight polygonal lines connect Dubai, Cyprus, London, Athens, Cairo, Sofia, Belgrade, Damascus and Moscow, reflecting the new geography of parasitic capital with no growth prospects in the carriage bag of its travellers. In this Eastern and Middle Eastern geographical architecture, Athens was a key pawn and conduit in the service of financialisation and neo-liberalism. It should be noted that the amount of tax evasion of this new super-rich comprador along with financial class was enormous.

None of the above activities was conducive to growth. Greek investments in the real economy involved small and medium size enterprises in the textile and brewing industries in Greece and the Balkans, but this could neither offset nor arrest the new domination by financial and rentier/comprador capital, that is the capital of debt, corruption and tax evasion. ${ }^{4}$ Simitis' 'modernisation' and 'anti-populist' programme co-constituted this new reality which penetrated deeply into Greece's social tissue, destroying the social mores and culture of working class and agrarian communities. As the organic produce became increasingly replaced by the imported GM product of the core, the best the local producer could do was to embrace the international domination of his/her market becoming a petty comprador. At the same time, Simitis created a new type of social alliance, the 'social alliance of modernisation', gathered around the 'party of the stock exchange' and unified via a complex paralegal corruption network forming a new bi-partisan consensus across the trembling party system of post-1974 Greek politics. PASOK and ND were now united behind a range of wheeling and dealing related to acts of privatization, management of state financial flows and recycling of debt, defence

\footnotetext{
${ }^{3}$ Greek shipping capital, a prime international force in world seaborne trade with no substantial base in Greece, should also be brought into equation. Also, part of the Greek merchant fleet is listed in the shipping register under flags of convenience, so no substantial tax income can be raised by the Greek state. This loss of income becomes even more significant in the 1990s and 2000s, as the world share of the Greek merchant fleet - under confirmed Greek ownership - which was $1 \%$ in 1947 and $12 \%$ in 1970, soared to $17.4 \%$ in 2000. Unlike other nationalities, Greek ship-owners are under no legal compulsion to enter or remain on the Greek registry and they do so only in periods in which favourable tax regimes - such as laws 2687/1953, 89/1967 and 378/1968come into force. Most Greek shipping is 'tramp', rather than 'liner' shipping. The former is conducted by vessels, which go like taxis wherever the charterer wants, with freight rates fixed in a free global market. The latter is conducted by vessels/liners, which run like buses on regular schedules and according to predetermined routes and tariffs. Having said this, the only significant contribution of Greek shipping to the Greek economy is its net contribution to invisible earnings and employment.

${ }^{4}$ Even in the middle of the debt crisis in September 2011, Athens daily press reported that Mytilineos S.A. buys from the state electricity company, DEI (PPC S.A.), energy at 41 Euros per MegaWh, only to sell it back to DEI for Euros 55 per MegaWh. How is this possible? Mytilineos, who runs aluminium business, received a licence by the Greek state to buy cheap electricity for his aluminium business. But he had set up a separate energy unit for himself, ending up selling back energy to DEI at a higher price. This type of domestic comprador activity against the very interests of the public at large is not just damaging to state performance; it is insulting. None of the press reports about it have been denied or contradicted.
} 
expenditure (see below), re-arrangement of privileges and re-distribution of benefits and political clientele. It can be argued, therefore, that despite the fact that the class determinants of the Greek bourgeoisie had been changing, the coalition of power and the structure of the ruling bi-partisan class, including the large number of civil servants, remained unaltered. The structures of dependency and subordination of the Greek state elites to Euro-Atlantic power centres also remained the same.

Neither Simitis' 'modernisation' and 'anti-tax evasion' program (1996-2004), nor the similar 'modernisation' program pursued by the ND cabinet under Karamanlis Jr. (2004-09) brought any benefit to state finances. According to multiple announcements by the Ministry of Finance in September-October 2011, more than 6,000 individuals owe more than 150,000 Euros each one of them to the Inland Revenue. For the sake of comparison, the total amount these individuals owe to the tax authorities are in the region of 30 billion Euros, whereas the annual spending of the Greek state for wages is less than 23 billion Euros. No accident, therefore, that the public debt doubled from 2000 to 2009, and at the expense of the average Greek consumer. Yet this abrupt rise was not accompanied by an increase in the productive output of the economy, as the country's GDP presented a less dynamic structure (table 6). Interestingly, if we also factor in defence spending, justified was purely on ideational rather than real grounds, this dimension of public spending did not only add onto the debt structures of the country, but also extended corrupt practices to the heart of the state.

One of the reasons why France, in the first place, and Germany were the main holders of Greek debt is because Greek political elites, in their 'patriotic attempts' to move away from the USA's pro-Turkish grip, began using French and German weapons suppliers. By exaggerating both the threat coming from Turkey and Greece's and Cyprus's own vulnerability, the 'realists' of the Greek cabinets could bid for high-tech expensive military gear: in 2009 defence expenditure in Greece was over 3.3 per cent of GDP, as opposed to 2.4 per cent for France, 2.7 per cent for Britain, 2 per cent for Portugal, 1.4 per cent for Germany, 1.3 per cent for Spain and 4.7 per cent for the USA. At the beginning of the full-fledged crisis of 2010, Greece bought six warships from France at a cost of 2.5 billion Euros and six submarines from Germany at 5 billion Euros. Between 2005 and 2009 Greece was one of the largest European importers of weaponry. During that period, the purchase of $26 \mathrm{~F}-16 \mathrm{~s}$ from the USA and 25 Mirage-2000 from France represented nearly 40 per cent of the total import volume of the country. According to SIPRI (Stockholm International Peace Institute) data for 2006-2010, Greece is the fifth weapons importer of the world, with a global quota of 4 per cent, about half that of India (9 per cent), and two thirds of China's imports ( 6 per cent) - it is worth noting that the Chinese GDP is about twenty times bigger than Greece's nominal GDP (Fouskas \& Dimoulas 2013) Most of these transactions took place through the Greek state issuing debt, that is, pieces of paper. In Greece, there is no such thing as an 'industrial-military complex', but rather a comprador-military complex, a key faction within the wider financial/comprador oligarchy network, which is dominated by the Ministry of Defence, doing all sorts of wheeling and dealing under the radar of a liberal Constitution and the taxpayer. In 2011-12, for example, Akis Tsochatzopoulos, a highly regarded PASOK cadre who challenged Simitis in the party leadership in 1996, was being investigated and imprisoned with regard to his activities as Minister for National Defence between 1996 and 2001. Accusations against 
him include bribes he and his associates received for defence systems - mainly submarines and Patriot batteries - that were bought under his leadership. Thus, the entire security of the country is a dependent spoke of the Euro-Atlantic core, whether American or Franco-German.

\section{EU transfers to Greece and the PIGS cannot stop the debt spiral}

Having said this, the doubling of the Greek public debt from 2000 to 2009 (table 6) should not be surprising. In addition, we can see from the table the increase of extra charges for the Greek taxpayer $\left(5^{\text {th }}\right.$ column $)$ all of which had been happening without any corresponding increase in productivity and output. The Greek GDP has been growing at a much slower pace than the debt ( $3^{\text {rd }}$ and $4^{\text {th }}$ columns). The ruling parties of ND and PASOK became increasingly unable to manage the debt. The structural funds coming from the EC/EU also did very little, if anything at all, to improve social cohesion and productivity in Greece and other PIGS (tables 4 and 5). A careful look at the empirical evidence we possess suggests that during 2000-09 EU transfers towards the PIGS never went above 1.53 per cent of GDP, or 220 Euros per person per annum. In fact, the so-called structural and cohesion funds disintegrated the productive structures of the PIGS even further, instead of advancing sustainable development, real growth and socioeconomic cohesion.

Table 4: Impact of the EU structural funds in Cohesion (PIGS) Countries, 1986-2006

\begin{tabular}{|l|l|l|l|l|l|l|l|l|l|}
\hline & $\begin{array}{l}\text { Gross Value Added } \\
\text { (GVA \% per annum) }\end{array}$ & \multicolumn{2}{l|}{$\begin{array}{l}\text { Investment } \\
\text { Knowledge-ICT } \\
\text { per annum) }\end{array}$} & $\begin{array}{r}\text { in } \\
(\%\end{array}$ & \multicolumn{2}{l}{$\begin{array}{l}\text { Labour } \\
\text { (\% per annum) }\end{array}$} \\
\hline Country & $\mathbf{8 6 - 9 3}$ & $\mathbf{9 4 - 9 9}$ & $\mathbf{0 0 - 0 6}$ & $\mathbf{8 6 - 9 3}$ & $\mathbf{9 4 - 9 9}$ & $\mathbf{0 0 - 0 6}$ & $\mathbf{8 6 - 9 3}$ & $\mathbf{9 4 - 9 9}$ & $\mathbf{0 0 - 0 6}$ \\
\hline Greece & 2.63 & 3.19 & 3.36 & -0.01 & -0.03 & -0.02 & 0.974 & 0.883 & 0.576 \\
\hline Spain & 0.60 & 1.55 & 1.96 & -0.01 & -0.03 & -0.04 & 0.193 & 0.565 & 1.008 \\
\hline Ireland & 2.86 & 3.52 & 2.72 & 0.03 & 0.12 & 0.16 & 0.981 & -0.106 & 0.407 \\
\hline Portugal & 3.58 & 5.63 & 4.78 & -0.02 & -0.03 & -0.05 & 0.724 & 1.882 & 1.671 \\
\hline
\end{tabular}

Source: Our compilation of data from GHK (2002) and GHK/PSI/IEEP/EC (2003)

Table 5: EU cohesion funds committed to PIGS, 2000-09 (in 1999 prices). 


\begin{tabular}{|c|c|c|c|c|}
\hline Country & Total resources & $\begin{array}{l}\text { Per } \\
\text { person/per } \\
\text { annum }\end{array}$ & $\begin{array}{l}\text { Percentage of } \\
\text { National GDP }\end{array}$ & $\begin{array}{l}\text { Cumulative } \\
\text { Impact in GDP } \\
2000-09\end{array}$ \\
\hline Greece & $\begin{array}{l}23.80 \quad \text { billion } \\
\text { Euros }\end{array}$ & 220 Euros & 1.25 & 15.89 \\
\hline Spain & $\begin{array}{ll}54.30 \quad \text { billion } \\
\text { Euros }\end{array}$ & 140 Euros & 0.62 & 16.67 \\
\hline Ireland & 3.76 billion Euro & 100 Euros & 0.25 & 7.47 \\
\hline Portugal & $\begin{array}{l}22.50 \quad \text { billion } \\
\text { Euros }\end{array}$ & 220 Euros & 1.53 & 16.75 \\
\hline
\end{tabular}

Sources: Our compilation of data from EU (2010) and Martin, R. (2003)

Moreover, the import/export ratio from 1994 to 2009 shrank at the expense of exports and despite significant growth. Thus, the international competitive position of Greece worsened, the export-led manufacturing sector disintegrated further, and all this despite high borrowing and the rise in the share price index of the ASE. Further, the structure of exports over imports shows the magnitude of the problem, caused by a combination of the uneven development between the core and the peripheral Greek state and of the policies pursued by the 'new' coalition of power (PASOK + ND + new financial comprador bourgeoisie) straddling the geopolitical fault-lines of the country. From 1994 to 2009 the Greek economy lost almost 40 per cent of its competitiveness despite the fact that GDP growth remained relatively good, whereas the period 1999-2004 was the highest in the EU; domestic and external borrowing increased; and the ASE's price index was doing quite well. In this respect - manipulation of statistics apart - the relatively wealthy picture of the Greek economy before the current crisis was not because of the improvement of the real economy, but rather to the speculative, rentier and consumerist activities of the new business and middle classes, coupled with the recycling of European/German financial surpluses in the country's account and banking system. In other words, as elsewhere in the West, especially in the USA and the UK, the growth registered was debt-driven, whereas the disintegration of the domestic economy from the mid-1990s onwards went hand in glove with the relative growth of comprador together with financial elements substantial increase of imports of financial products and increase of financialisation through the ASE and external and domestic borrowing via banking mediation. The aim of the EuroAtlantic powers was crystal clear: use the new bipartisan power coalition of 'modernisers' in Greece to penetrate the Balkans and the Near East not just for financial/speculative purposes, but also for geopolitical reasons. These involve, for example, contribution of Greece to the stabilisation of Albania, Bulgaria and FYROM/Macedonia, while maintaining the balance of power in the Aegean and Cyprus. In this context, the crisis that broke up in 1996 between Greece and Turkey over the uninhabited islands of Imia/Kardak, as well as over the transfer of S-300 Russian missiles to Cyprus, not to mention the case of the Kurdish rebel, Abdullah 
Ocalan in 1999, or the crisis over FYROM's name, still lingering, need to be remembered. Moreover, financialisation and expansion of banking capital across South-east Europe from the mid-1990s onwards induced a policy of rapprochement between Greece and Turkey, which was short-lived and opportunistic as indeed all arrangements sponsored by comprador capital and financiers. All of these problems, of course, and despite the fact that none of them benefitted Greece's geopolitical and security interests, had been duly exploited by the bipartisan power bloc pushing for an increase in defence spending, that is the purchasing of weaponry by issuing pieces of paper (debt). During the era of neo-liberal financialisation, Greece's dependent/subaltern position in international and European politics deepened further along with the disintegration of the productive base of the country.

Table 6: Evolution of the Greek public debt and its relation to GDP in USD

\begin{tabular}{|c|c|c|c|c|c|}
\hline Year & Public debt & Annual change & $\begin{array}{l}\text { \%annual } \\
\text { change } \\
\text { in GDP }\end{array}$ & $\begin{array}{l}\text { Public debt } \\
\text { per person }\end{array}$ & $\begin{array}{l}\text { \%annual } \\
\text { change in } \\
\text { public } \\
\text { debt per } \\
\text { person }\end{array}$ \\
\hline 2000 & $139,689,071,038$ & $10,087,641,291$ & 100 & $12,840.70$ & 100 \\
\hline 2001 & $149,776,712,329$ & $28,884,931,507$ & 107.2 & $13,701.68$ & 106.7 \\
\hline 2002 & $178,661,643,836$ & $47,538,356,164$ & 119.3 & $16,293.75$ & 118.9 \\
\hline 2003 & $226,200,000,000$ & $47,538,356,164$ & 126.6 & $20,602.64$ & 126.4 \\
\hline 2004 & $272,540,983,607$ & $46,340,983,607$ & 120.5 & $24,820.27$ & 120.5 \\
\hline 2005 & $271,193,150,685$ & $-1,347,832,922$ & 99.5 & $24,701.92$ & 99.5 \\
\hline 2006 & $287,170,808,219$ & $15,977,657,534$ & 105.9 & $26,211.64$ & 106.1 \\
\hline 2007 & $329,765,753,425$ & $42,594,945,206$ & 114.8 & $30,014.36$ & 114.5 \\
\hline 2008 & $346,575,409,836$ & $16,809,656,411$ & 105.1 & $31,555.10$ & 105.1 \\
\hline 2009 & $385,542,465,753$ & $38,967,055,917$ & 111.2 & $35,082.30$ & 111.2 \\
\hline 2010 & $378,241,095,890$ & $-7,301,369,863$ & 98.1 & $34,419.71$ & 98.1 \\
\hline 2011 & $375,772,602,740$ & $-2,468,493,150$ & 99.3 & $34,172.04$ & 99.3 \\
\hline 2012 & $393,420,821,918$ & $17,648,219,178$ & 104.7 & $35,741.33$ & 103.8 \\
\hline
\end{tabular}


Source: Our compilation of data

from http://www.economist.com/content/global debt_clock

and Hellenic Statistical Agency (ELSTAT 2011)

The borrowing requirement of the Greek state increased rapidly after 2001. This was a result of further internationalisation/Europeanisation of the Greek state with the insertion of the country into this peculiar form of world money, the Euro. We see that whereas the initial loans were sourced domestically, this ceased to be the case after 2007, as the 2007-08 financial crisis wiped out the accumulated wealth of small paper-asset investors, while at the same time the Greek state was forced to pump money into the banks degrading the structure of the budget deficit. This, in turn, could not have been offset by European funds whose volume was not sufficient (table 7, column 4). It is clear to us that from 2007 onwards the Greek debt has been split between national and international/European agencies and structures. Thus, the 'haircut' agreed at the end of October 2011 and effected in the second bailout of February-March 2012, applied to the Greek banking sector, which found it impossible to survive without substantial re-capitalisation from EFSF funds. Time and again, this re-capitalisation was being carried out at the expense of the taxpayer, leading mathematically to a creditor-led default, as initially pushed for by Germany and as the third round of austerity in Fall 2012 showed. Greece is unable to service its debt or ever pay back some of the principal since the actual and projected rate of growth from 2010 to 2013 ranged between -2,5 per cent and -7,5 per cent, whereas the interest rate for borrowing has always been above 3 per cent. Moreover, the European banking system, too, seems to be unable to cope with the stress on its peripheral banks and pension funds inasmuch as the degree of leveraging takes on enormous proportions. Greek banks alone, for example, are dependent on ECB credit lines that amount to over 100 billion Euros (Fouskas $\&$ Dimoulas 2013). The new ruling classes of Greece, together with their Western masters, have failed spectacularly to deliver growth and sustainable development. What they deliver, though, is a peculiar form of 'creative destruction', whereby the mechanism of national and international debt generates forms of primitive accumulation, ie social destruction and pauperisation.

\begin{tabular}{|c|c|c|c|c|c|c|}
\hline & \multicolumn{5}{|c|}{$\begin{array}{l}\text { Table } 7 \text { Annual loans of the Greek State, state receipts, receipts from } \\
\text { EC/EU and expenditures }\end{array}$} & \\
\hline Year & $\begin{array}{l}\text { Domestic } \\
\text { Loans }\end{array}$ & $\begin{array}{l}\text { Foreign } \\
\text { Loans }\end{array}$ & $\begin{array}{l}\text { Receipts } \\
\text { from EC/EU }\end{array}$ & Receipts & Expenditures & $\begin{array}{l}\text { Receipts- } \\
\text { Expenditures }\end{array}$ \\
\hline
\end{tabular}




\begin{tabular}{|c|c|c|c|c|c|c|}
\hline $\begin{array}{l}\text { 1998(million } \\
\text { drachmas) }\end{array}$ & $9,609,693$ & $1,344,888$ & 98,202 & $9,521,604$ & $21,378,017$ & $\begin{array}{c}- \\
11,856,413\end{array}$ \\
\hline $\begin{array}{l}\text { 1999(million } \\
\text { drachmas) }\end{array}$ & $8,365,025$ & $1,272,140$ & 114,189 & $10,626,457$ & $21,253,001$ & $-10,626,544$ \\
\hline $\begin{array}{l}\text { 2000(million } \\
\text { drachmas) }\end{array}$ & $5,454,921$ & $1,695,821$ & 119,077 & $12,186,488$ & $21,602,748$ & $-9,416,260$ \\
\hline $\begin{array}{l}\text { 2001 thousand } \\
\text { euro }\end{array}$ & $14,990,301$ & $1,773,632$ & $2,658,226$ & $41,021,321$ & $60,443,281$ & $-19,421,960$ \\
\hline $\begin{array}{l}\text { 2002thousand } \\
\text { euro }\end{array}$ & $29,956,909$ & 379,321 & $1,371,316$ & $37,437,431$ & $69,144,977$ & $-31,707,546$ \\
\hline $\begin{array}{l}\text { 2003thousand } \\
\text { euro }\end{array}$ & $35,934,079$ & $2,034,098$ & $1,052,393$ & $37,866,221$ & $76,952,341$ & $-39,086,120$ \\
\hline $\begin{array}{l}\text { 2004thousand } \\
\text { euro }\end{array}$ & $40,165,350$ & $9,882,539$ & $2,810,607$ & $39,859,803$ & $92,781,544$ & $-52,921,741$ \\
\hline $\begin{array}{l}\text { 2005thousand } \\
\text { euro }\end{array}$ & 39.416 .790 & $5,379,852$ & $2,623,819$ & $42,969,056$ & $90,437,198$ & $-47,468,142$ \\
\hline $\begin{array}{l}\text { 2006thousand } \\
\text { euro }\end{array}$ & $27,439,833$ & $9,715,000$ & $3,563,523$ & $47,363,182$ & $88,122,280$ & $-40,759,098$ \\
\hline $\begin{array}{l}\text { 2007thousand } \\
\text { euro }\end{array}$ & $35,822,354$ & $25,544,219$ & $4,810,946$ & $49,962,035$ & $116,178,904$ & $-66,226,868$ \\
\hline $\begin{array}{l}\text { 2008thousand } \\
\text { euro }\end{array}$ & $34,906,408$ & $34,754,244$ & $4,668,300$ & $52,530,042$ & $126,912,696$ & $-74,382,654$ \\
\hline \multicolumn{7}{|c|}{$\begin{array}{l}\text { Source: Calculations based on data from the Concise Statistical Yearbooks of ELSTAT for the respective } \\
\text { years. Hellenic Statistical Agency (ELSTAT) }\end{array}$} \\
\hline
\end{tabular}

Table 8: Annual change of export over imports, the share prices in Athens stock exchange and Gross Domestic Product in market prices 


\begin{tabular}{|c|c|c|c|}
\hline Year & $\begin{array}{l}\text { \%exports } \\
\text { over } \\
\text { imports }\end{array}$ & $\begin{array}{l}\text { Share Price } \\
\text { Indices }\end{array}$ & $\begin{array}{l}\text { Dome } \\
\text { produ } \\
\text { marke }\end{array}$ \\
\hline 1994 & 43.9 & & 110,9 \\
\hline 1995 & 43 & 914.15 & 110,9 \\
\hline 1996 & 41.4 & 933.8 & 107.4 \\
\hline 1997 & 41 & 1.479 .63 & 106.8 \\
\hline 1998 & 35.9 & 2.737 .6 & 105.2 \\
\hline 1999 & 36.3 & 5.535 .1 & 103 \\
\hline 2000 & 35.1 & 3.388 .9 & 103.4 \\
\hline 2001 & 36.8 & 1.748 .4 & 104.2 \\
\hline 2002 & 31.5 & 2.263 .6 & 103.4 \\
\hline 2003 & 29.8 & 2.263 .2 & 105.9 \\
\hline 2004 & 29.1 & 2.786 .2 & 104.4 \\
\hline 2005 & 32 & 3.663 .9 & 102.3 \\
\hline 2006 & 32.4 & 4.394 .13 & 105.2 \\
\hline 2007 & 30.9 & 5.178 .83 & 104.3 \\
\hline 2008 & 28.6 & 1.786 .51 & 101 \\
\hline 2009 & 36.3 & 2.196 .16 & 98 \\
\hline 2010 & 28.7 & $1,413.94$ & 95.5 \\
\hline
\end{tabular}

Source: ELSTAT. Our compilation of data from the Concise Statistical Yearbooks and the National Accounts of Greece.

There is no doubt, therefore, that whereas the trade deficit and various forms of external borrowing especially during the period of low interest rates are substantial sources of the 
overall Greek debt, numerous other factors, mainly of domestic origin, have to be factored into every calculation. Trade deficits are articulated in the current account, and especially in the structure of the unequal/un-equivalent trade interaction between Greece and the European core, particularly Germany, Italy, France and the Netherlands. Approximately 70 per cent of Greek imports come from Europe, whereas about 55 per cent come from EU member states. Germany's share of total imports is 12 per cent, Italy's 11 per cent and France's 6 per cent. Of the total of Greek exports, some 64 per cent goes to EU member states (11.5 per cent to Germany, 11 per cent to Italy, 4.2 per cent to France). On the surface, it appears that the import/export relation is in equilibrium, but this is not the case. In terms of absolute value, Greek exports to Germany are in the region of 1.9 billion Euros, whereas the value of German exports to Greece are in the region of 7.2 billion Euros (Fouskas \& Dimoulas 2013). But there is also the dimension of financial account. This can take various forms: FDI, portfolio flows and other flows driven by the banking sector of the core. Recycling of German surpluses becomes clear from the overall composition of German exports over imports, thus accelerating the pace of concentration of the overall debt. In this context, the analyses by Lapavitsas et al. are meaningful:

[I]nternational transactions of Euro-zone countries have been driven by the requirements and implications of monetary union. Peripheral countries have lost their competitiveness relative to Germany because of initially high exchange rates as well as because of the ability of German employers to squeeze workers harder. The result has been a structural current account surplus for Germany, mirrored by structural account deficits for peripheral countries. Consequently, German FDI and bank lending to the Euro-zone have increased significantly. 'Other' flows to peripheral countries rose rapidly in 2007-08 as the crisis unfolded, but then declined equally rapidly. That was the time when peripheral states were forced to appear in credit markets seeking funds (Lapavitsas et al. 2010, 344).

\section{Concluding remarks}

We can now draw a few conclusions:

a) Greece had always occupied a dependent/subaltern position in the global and European division of labour. The dominant class element in Greece's economy has always been of a comprador nature, that is, large import consortia and small commodity forms of production and consumption. As such, it followed economic developments and trends initiated outside Greece, rather than led them. The structures of dependency deepened further with Greece's insertion into the post-Bretton Woods financialised capitalism and the adoption of the Euro as its national currency in 2001. This disintegrated further the productive base of the country and 
increased its debt obligations. Greece had become far more uncompetitive within the Eurozone than it had been outside it.

b) The high growth rates of the post-1995 period in Greece are not a result of the improvement of the real economy (productivity, technological innovation, output and valorisation), but due to the speculative and consumerist activities of middle-to-upper middle classes and the comprador together with financial elements that have dominated the Greek social formation since then. The Athens Stock Exchange and off-shore business interests escaping taxation, coupled with aggressive penetration of the Greek banking sector in the Balkans/Near East/North Africa - which was basically used as a conduit of German and French financialisation plans for the region - constituted the form that 'asset price Keynesianism' (Robert Brenner) assumed in Greece. Alongside this picture one can draw the profile of the new comprador bourgeoisie, the main agent of dependency for the country. The main difference with the comprador element of the past is that this time around the commodity traded is primarily, but not exclusively, fictitious rather than real. Financialisation and neo-liberalism have shattered the country's already weak productive-material base.

c) The entry of the country into the Euro-zone has accelerated the proliferation of the country's debt but, as such, it did not cause it. Our findings indicate that a Greek bankruptcy would have happened anyway, as it happened in the past and when the country was not participating in any currency union - having its currency pegged to an imperial currency was enough to cause havoc. Greece has never really been solvent. Bankruptcy was bound to happen much earlier had it not been for the geopolitical and security circumstances of the end of the Cold War and the need for the Euro-Atlantic powers - especially the US - to have (and use) Greece and Turkey as anchors of stability in the Balkans and the Near/Middle East. Greece was used by Germany as a platform for the financialization of the Balkans and the Near East.

d) The sources of the Greek debt crisis are both internal and external and, in general, pertain to the historical fault-lines of the country: a weak capitalist economic structure relative to the advanced core; and a relatively important geopolitical/regional position relative to its real economic assets and industrial/technological base. The management of those fault-lines by the coalition of PASOK-ND in the post-1974 period proved, as in the past, to be subordinate to the class and security interests of the core, unable to articulate independent, national/class claims against it. The party system remained a wholly dependent spoke of the Euro-Atlantic hub and a corrupt administrator in managing the relation of representation between itself and civil society. Myriad of financial, geopolitical and class interests, hemmed in by corrupt deals, cut across the vertical articulation of corporatist interests between PASOK-ND and civil society, on the one hand, but also the horizontal articulation between PASOK-ND and the EuroAtlantic core, on the other. From this perspective, as we have argued elsewhere, this Greek tragedy is the making of the Greek and Euro-Atlantic ruling classes (Fouskas 2011). Sadly, the new radical party of Syriza seems also unable to confront the corrupt structures of subordination and dependency of the country on the Euro-Atlantic core and the new financial comprador element. 


\section{Bibliography}

Aglietta, M (2008), 'Understanding the structured credit crisis', La Lettre du CEPII, 275, Paris, France: Centre d' Etudes Prospectives et d'Informations Internationales

Bank of Greece $(1998,2011)$, Annual Reports of the Governors, Athens: Bank of Greece

Brenner, R. (2003), The Boom and the Bubble. The US in the World Economy, London, UK: Verso

Brenner, R. (2006), The Economics of Global Turbulence, London, UK: Verso

Busch, K. (1976), Die Krise der Europäischen Gemeinschaft, Hamburg, Germany: Europaische Verlagsanstalt

Chase, James (1999), Acheson. The Secretary of State that Created the American World, New York, USA: St. Martin's Press

Dellas and Darvas, $Z$ et al. (2012), 'A comprehensive approach to the Euro-area debt crisis', Brussels, Belgium: Bruegel, available at https://ideas.repec.org/p/mkg/wpaper/1101.html (accessed 16 January 2013)

Duncan, R. (2012), 'A new global depression', New Left Review, 77, 1-21

Epstein A., Gerald and M. H. Wolfson (2013), 'Introduction: The political economy of financial crisis' in Wolfson H., M and Gerald Epstein (eds) The Political Economy of Financial Crises, Oxford, UK: Oxford University Press, pp.1-20

EU (2010) Ex-post Evaluation of Cohesion Policy Programs 2000-06 Co-financed by EFDF. Synthesis Report

Fine, B. (2010), 'Locating financialisation', Historical Materialism, 18, 97-116 
Fouskas K., Vassilis (1998), Italy, Europe, the Left. The Transformation of Italian Communism and the European Imperative, Aldreshot, UK: Ashgate

Fouskas K., Vassilis and Bülent Gökay (2005), The New American Imperialism. Bush's War on Terror and Blood for Oil, Connecticut, USA: Praeger

Fouskas K., Vassilis and Bülent Gökay (2012), The Fall of the US Empire. Global Fault-lines and the Shifting Imperial Order, London, UK: Pluto press

Fouskas K., Vassilis and Dimoulas, Constantine (2013), Greece, Financialization and the EU. The Political Economy of Debt and Destruction, New York and London, USA and UK: Palgrave-Macmillan

Fouskas K., V. and C. Dimoulas (2012), 'The Greek workshop of debt and the failure of the European project', Journal of Balkan and Near Eastern Studies, 14, (1), pp.1-33

Fouskas, K. V. (1997), 'The Left and the crisis of the Third Hellenic Republic, 1989-1997' in Sassoon, D. (ed), Looking Left, London, UK: I.B. Tauris, pp.64-88

Frank, A. G. (1972), Lumpenbourgeoisie, Lumpendevelopment, New York, USA: Monthly Review Press

Freris, A (1986), The Greek Economy in the 20th Century London and Sydney: Croom Helm

GHK (2002) The Thematic Evaluation on the Contribution of the Structural Funds to Sustainable Development" EC: DG Regio

GHK/PSI/IEEP/EC (2003), The Contribution of the Structural Funds to Sustainable Development. A Synthesis Report (Volume 1, chapter 4), EC: DG Regio

Glyn, A. (2007), Capitalism Unleashed, Oxford, UK: Oxford University Press 
Gowa, J (1983), Closing the Gold Window. Domestic Politics and the End of Bretton Woods, New York, USA: Ithaca

Gowan, P. (1999), The Global Gamble. Washington's Faustian Bid for World Dominance London, UK: Verso

Hellenic Statistical Agency (ELSTAT) Concise Statistical Yearbooks for the Years 1980-2011, Athens: ELSTAT

Lapatsioras, S. et al. (2009) 'On the character of the current economic crisis' Radical Notes www.radicalnotes.com

Lapavitsas, C. et al. (2010), 'Euro-zone crisis: Beggar thyself and beggar neighbour', Journal of Balkan and Near Eastern Studies 2 (4), 330-368

Lapavitsas, C. (2013), Profiting without Producing. How Finance Exploits us All, London, UK: Verso

Lapavitsas, C. (2011) et al. Breaking Up? RMF, SOAS

Manolopoulos, C (2011) The Greek Economy and the Banking Sector, Athens: Marfin Investment Bank

Martin, R (2003) The Impact of the EU's Structural and Cohesion Fund on Real Convergence in the EU, Brussels: European Central Bank

Michalopoulos, G. (2012), Financing Greek Banks during the Crisis, Athens, Greece: Alpha Bank

Milios, Y. and Dimitris Sotiropoulos (2010) 'Crisis of Greece or crisis of the Euro?' Journal of Balkan and Near Eastern Studies 12(3) 
Milios Y. and Ilias Ioakeimoglou (1990) The Internationalisation of Greek capitalism and the Balance of Payments (in Greek) Athens: Exantas

Mundell, R. (1961) 'A theory of optimum currency area', American Economic Review 51(4), $657-665$

Hobsbawm, E. (1995), Age of Extremes, London, UK: Abacus.

Pagoulatos, G. and C. Triantopoulos (2009), 'The return of the Greek patient: Greece and the 2008 global financial crisis', South European Society and Politics, 14 (1), 45-58

Palloix, C. (1975), L' internationalisation du capital, Paris, France: F. Masperó

Panitch, L and S. Gindin (2012), The Making of Global Capitalism London, UK: Verso

Pavlopoulos, P. (2011) 'What the bailouts want to achieve is unconstitutional' www.olypmia.gr (in Greek, 12 October)

Poulantzas, N. (1974), Les classes sociales dans le capitalism aujourd'hui, Paris, UK: F. Masperó

Sassoon (1986), Contemporary Italy, London, UK: Longman

Sassoon, D. (1996), One Hundred Years of Socialism, London, UK: I.B. Tauris

Stockhammer, E. (2013) 'Financialization and the global economy', in Wolfson H., Martin and Gerald A. Epstein (eds) The Political Economy of Financial Crises, Oxford, UK: Oxford University Press, pp.512-526

Tolios, Y. (2011), Crisis, 'Odious' Debt and Violation of Payments, Athens, Greece: Topos (in Greek)

Union of Greek Banks (2011), The Greek Banking System Athens, Greece: UGB 
Varoufakis, Y (2015) Conversation with Lamond and Mars, Dromos tis Aristeras (in Greek, 17 July)

Wolf, M. (18 June 2013), 'The toxic legacy of the Greek crisis', Financial Times

Wolf, M. (3 October 2012) Lecture at Richmond University London, mimeo 